\title{
PENGEMBANGAN SISTEM INFORMASI PENGGAJIAN (SEBUAH PENDEKATAN STUDI KASUS)
}

\author{
Sugiarto Hartono \\ Program Sistem Informasi, Program Studi Sistem Informasi, Universitas Bina Nusantara \\ Jln. K.H. Syahdan No. 9, Palmerah, Jakarta Barat, 11480 \\ Telp. (021) 5345830 \\ E-mail: shartono@binus.edu
}

Rouly Doharma

STMIK Widuri, Jakarta

E-mail:dohar_05@yahoo.com

\begin{abstract}
ABSTRAKSI
Penelitian ini bertujuan untuk memberikan solusi atas permasalahan absensi dan penggajian manual pada PT ASL. Penelitian ini menggunakan metode Analisis Object-Oriented Analysis and Design (OOAD), pengakuan beban gaji berdasarkan SAK-ETAP Bab 23, dan perhitungan pajak penghasilan pasal 21 dengan menggunakan gross method. Hasil dari analisis dan perancangan sistem informasi akuntansi penggajian diharapkan PT ASL dapat memiliki sistem informasi akuntansi penggajian yang terintegrasi antara pencatatan waktu kehadiran dan pengajuan cuti/izin, dinas, dan lembur sehingga diharapkan dapat mengurangi kesalahan perhitungan gaji karyawan, perusahaan dapat menghasilkan laporan yang berguna bagi pemangku kepentingan untuk membantu pengambilan keputusan, perusahaan dapat menerapkan pengendalian internal yang memadai untuk mengurangi fraud yang merugikan bagi pihak perusahaan maupun pihak karyawan.
\end{abstract}

Kata Kunci: Pengembangan Sistem, Sistem Informasi Penggajian, Penggajian 


\section{PENDAHULUAN}

Perkembangan teknologi informasi yang cepat sangat berpengaruh pada aspek kehidupan manusia, terutama pada organisasi bisnis dimana teknologi infomasi dapat memberikan organisasi kecepatan dan keakuratan dalam pengambilan keputusan. Menurut Chuang (2015)"a firm can maintain its competitiveness by consecutively building up and making good use of its own business advantages through accumulating core resources and abilities, that is, invisible assets such as knowledge, technology, and human resources. Of the various types of intellectual capital, investment in information technology and its application is one of the ways to create invisible value, therefore IT can bring a high level of both visible and invisible benefits for an organization.

Keberhasilan perusahaan tidaklah terlepas dari peran karyawan yang turut serta bekerja dan membantu untuk mencapai visi dan misi perusahaan. Karyawan merupakan ujung tombak perusahaan dimana karyawan dapat berinteraksi secara langsung dengan pelanggan dan menjadi cerminan umum perusahaan. Menurut Frank (2015), "Employees are becoming the ultimate reputation makers or breakers in a world, where every organisation sells experiences rather than products and where the truth is more accessible and shareable than ever - particularly by those on the "inside".

Sistem Informasi Akuntansi dibutuhkan perusahaan ketika memasuki bidang teknologi informasi sebagai sarana untuk membantu manajemen dan kontrol yang berkait dengan area ekonomi dan Financial. Menurut Grande, Estebanez, dan Colomina (2011) menyatakan bahwa keuntungan utama dalam penggunaan Sistem Informasi Akuntansi adalah perusahaan dapat lebih mudah beradaptasi terhadap perubahan lingkungan, pengelolaan transaksi dan laporan lebih baik serta meningkatkan daya saing perusahaan. Penerapan SIA juga mendorong perusahaan untuk lebih dinamis dan meningkatkan hubungan external antar perusahaan.

Penerapan Sistem Informasi Akuntansi Penggajian dibutuhkan untuk membantu perusahaan dalam mengelola gaji karyawan secara akurat, mengurangi beban pekerjaan bagian HRD, serta membantu manajemen untuk meningkatkan pengendalian internal, sehingga dapat menghindari bentuk kecurangan yang merugikan karyawan dan perusahaan. Menurut Menurut Yakal (2014), "Payroll system is important for company because it's the most complex element of any accounting system. It's also the scariest. Not only you do have to produce checks and direct deposits that are 100 percent accurate, but you have to make certain that the underlying calculations--taxes and benefits and other withholding--are also correct to the penny. And you must submit taxes and filings to the IRS and other taxing agencies on time or risk fines and other penalties."

PT ASL merupakan perusahaan penyedia jasa end-toend dalam bidang $\neg$ e-commerce yang saat ini memiliki 658 karyawan secara keseluruhan. Sampai saat ini PT ASL belum menerapkan sistem informasi absensi dan penggajian yang terintegrasi sehingga mengakibatkan proses absensi dan penggajian memiliki beberapa kelemahan. Beberapa kelemahan sistem absensi dan penggajian PT ASL yaitu pencatatan absensi karyawan masih menggunakan cara manual, proses absensi belum terintegrasi dengan cuti/izin dan penugasan dinas karyawan, serta proses pengajuan cuti/izin dan penugasan dinas masih secara manual dan belum memiliki perhitungan kuota cuti secara otomatis.

Kelemahan lain yang dihadapi oleh PT ASL adalah proses pencatatan waktu lembur dan perhitungan lembur dilakukan manual dengan memasukan jam lembur karyawan satu persatu ke dalam Microsoft Excel serta belum memiliki pengendalian internal yang memadai dalam pendataan karyawan dan perhitungan gaji karyawan. Menurut penelitian yang dilakukan oleh Dinapoli (2011) menyatakan bahwa biaya penggajian pada perusahaan Distd merupakan biaya operasional perusahaan yang besar dan signifikan yang mencapai $51 \%$ dari pengeluaran biaya tahunan perusahaan. Oleh karena itu penting bagi perusahaan untuk memiliki sistem pengendalian internal yang efektif untuk mengurangi kecurangan terhadap proses penggajian. Komponen yang penting dalam pengendalian internal adalan pemisahan kerja yang tepat untuk memastikan tidak hanya satu orang yang memiliki kontrol atas semua tahap transaksi dan pembatasan hak akses terhadap data personal dan finansial. Selain itu, PT ASL menggunakan vendor untuk menghitung pemotongan pajak penghasilan karyawan Menurut Hall (2011 : 277), "The risks associated with outsourcing are nontrivial. One is that an outside organization will have access to extremely confidential employee data and to the client firms's financial resources. Another risk is that the service provider will have a poor internal control and/or act incompetenly in a way that causes material errors or fraud. A client organization may outsource any function it chooses, but it cannot outsource its responsibility for implementing adequate internal control".

\section{METODE PENELITIAN}

Metodologi yang digunakan dalam penelitian ini adalah sebagai berikut :

\section{Studi Pustaka}

Studi pustaka dilakukan untuk melakukan pengumpulan data dengan cara mempelajari teori-teori yang terdapat pada buku, artikel, jurnal dan media informasi lainnya 


\section{Studi Lapangan}

Metode yang digunakan dalam studi lapangan terdiri atas 3 (tiga) cara, yaitu:

a. Wawancara

Wawancara dilakukan secara langsung dengan Head of a. Human Resources dan General Affair PT ASL padab. tanggal 5 November 2015 dan kepada payroll staff pada c. tanggal 8 April 2016. Wawancara tersebut dilakukan d. guna untuk mengetahui latar belakang perusahaan, visi, e. misi, proses absensi dan penggajian yang sedang berlangsung, masalah yang dihadapi, dan harapan 4. perusahaan akan penelitian ini bagi perusahaan.

\section{b. Dokumentasi}

Dokumentasi dilakukan dengan cara menelusuri bukti fisik yang terkait dengan proses penggajian seperti form absensi, form pengajuan cuti dan sakit, form perhitungan gaji yang menggunakan spreedsheet pada microsoft excel, serta form slip gaji.

\section{c. Observasi}

Observasi dilakukan secara langsung pada bagian fulfillment and delivery yang berada di Halim pada tanggal 25 november 2015 untuk melihat proses absensi karyawan harian dan Head Office yang berada di Sahid Sudirman Center pada tanggal 18 April 2016. Observasi dilakukan guna untuk melihat proses absensi dan penggajian pada PT ASL secara langsung.

\section{Metode Analisis dan Perancangan}

Metode perancangan menggunakan The Unified 1 . Process Life Cycle. The Unified Process (UP) merupakan metodologi pengembangan sistem yang $a$. berorientasi object yang terdiri dari :

\section{a. Inception Phase}

Merupakan tahapan perancangan yang paling awal. Pada tahap ini aktivitas yang dilakukan adalah mengumpulkan data dan informasi mengenai perusahaan meliputi latar belakang, visi, misi, proses penggajian yang sedang berjalan, serta masalah yang dihadapi oleh perusahaan dalam proses penggajian.

\section{b. Elaboration Phase}

Merupakan tahap lanjutan dari Inception Phase, dimana aktifitas yang dilakukan pada tahap ini meliputi menetapkan visi untuk sistem penggajian baru, menentukan ruang lingkup akhir, merancang arsitektur dan fungsi proses penggajian, memecahkan masalah yang mungkin dihadapi, dan menghasilkan estimasi waktu dan biaya yang realistis dalam pembuatan Sistem Informasi Akuntansi Penggajian.

\section{c. Construction Phase}

Pada Construction Phase kegiatan yang dilakukan adalah pembangunan perangkat lunak hingga dapat digunakan oleh PT. ASL, serta fokus pada pengendalian internal seperti validasi data dan pembatasan akses data, merancang user interface yang baik, serta menyelesaikan fungsi bantuan dan referensi kepada user.
Metode analisis yang digunakan dalam penyelesaian penelitian untuk PT ASL adalah dengan menggunakan metode Object Oriented Analysis and Design, yang terdiri dari:

Merancang usecase realization

Merancang system and user interface

Merancang software architecture

Merancang database

Merancang system security and control

\section{Metode Pencatatan Jurnal dan Standar Akuntansi}

Metode yang digunakan untuk pencatatan jurnal akuntansi menggunakan Standar Akuntansi Keuangan untuk Entitas Tanpa Akuntabilitas Publik (SAK-ETAP), dimana dalam penelitian ini SAK-ETAP Bab 23 mengatur tentang Imbalan Kerja yang diberikan oleh perusahaan harus diakui sebagai beban perusahaan.

\section{Metode Pembebanan Pajak Penghasilan Pasal 21}

Metode pembebanan Pph Pasal 21 karyawan menggunakan metode gross (gross method) dimana karyawan menanggung beban pajak penghasilannya sendiri. Dengan metode ini penghasilan yang diterima oleh karyawan akan berkurang sebesar Pph Pasal 21 yang dipotong oleh perusahaan.

\section{HASIL DAN DISKUSI}

Perancangan sistem informasi akuntansi penggajian ini juga dirancang dengan memiliki aktifitas pengendalian untuk meminimalisir resiko terjadinya kecurangan saat proses absensi dan penggajian, yaitu :

\section{Input Controls}

Auto-generate ID

b. Auto-generate waktu absensi karyawan

c. Completness control : memastikan user mengisi field yang wajib diisi.

\section{Access Controls}

a. Authentication: dengan menggunakan username dan password sewaktu melakukan Login di web, sistem akan mengetahui siapa saja users yang mengakses sistem.

b. Access Controll : menggunakan CRUD teknik untuk mengelompokan kegiatan users pada sistem.

- Login : Setip karyawan yang terdaftar dapat melakukan login

- Create Attendance : setiap karyawan dapat melakukan absen

- $\quad$ Update Attendance : Supervisor dan manager dapat mengupdate jam masuk dan jam pulang karyawan namun terbatas pada karyawan yang berada dalam 1 departemen saja.

- Create Leave Request: Setiap karyawan Full Time dapat mengajukan leave request. Jika karyawan tidak masuk karena sakit supervisor akan membuat leave request untuk karyawan tersebut.

- Update Authorization Leave Request : Manager dapat melakukan otorisasi leave request, namun untuk karyawan yang mengajukan sick leave, 
payroll staff yang akan melakukan otorisasi jika karyawan dapat menunjukan surat keterangan sakit dan dokumen pendukung.

- Create Overtime Request: supervisor dapat membuat overtime request dan manager dapat membuat overtime request jika supervisor berhalangan sehingga tidak dapat melakukan tugasnya.

- Create Overtime Realization: karyawan dapat melakukan relization overtime berdasarkan overtime request yang dibuat oleh supervisor/manager.

- Create Service Assignment: Supervisor dan manager dapat membuat surat pengajuan penugasan dinas.

- Update Authorization Service Assignment : hanya manager yang dapat melakukan otorisasi pengajuan penugasan dinas.

- Create Incentive: supervisor memasukan data jumlah pengiriman kedalam sistem.

- Update Incentive : supervisor dapat mengubah jumlah pengiriman jika terjadi kesalahan input

- Create Payroll : hanya payroll staff yang dapat memproses perhitungan penggajian karyawan.

- Update Payroll : payroll staff dapat mengubah jumlah nominal THR atau Bonus karyawan jika terjadi kesalahan input.

- $\quad$ Update Authorization Payroll : hanya HR manager yang dapat melakukan otorisasi penggajian karyawan.

- Create Schedule : Supervisor dapat membuat jadwal karyawan

- Update Schedule : Supervisor dapat mengubah jadwal karyawan jika terjadi perubahan jadwal

- View Schedule : karyawan dapat melihat jadwal individu melalui sistem

- View Payroll Report: karyawan dapat melihat laporan penggajian individu, supervisor dapat melihat laporan gaji karyawan yang berada dibawah pengawasannya. Manager dapat melihat semua laporan gaji karyawan yang berada di bawah pengawasannya namun hanya pada 1 departemen terkait. HR Manager dapat melihat semua laporan gaji karyawan, Finance Staff dapat melihat laporan gaji karyawan sebagai acuan pengeluaran kas.

- View Payroll Journal: Accounting staff dapat melihat jurnal penggajian.

- View Payslip: semua karyawan dapat mengakses payslip secara individu.

- View Attendance Report: karyawan dapat melihat laporan kehadiran secara individu, supervisor dapat melihat laporan kehadiran karyawan yang berada dibawah pengawasannya. Manager dapat melihat semua laporan kehadiran karyawan yang berada di bawah pengawasannya namun hanya pada 1 departemen terkait. HR Manager dapat melihat semua laporan.

- View Incentive Report : karyawan dapat melihat laporan insentif secara individu, supervisor dapat melihat laporan insentif karyawan yang berada dibawah pengawasannya. Manager dapat melihat semua laporan insentif karyawan yang berada di bawah pengawasannya namun hanya pada 1 departemen terkait. HR Manager dapat melihat semua laporan.

- View Income Tax Report : karyawan dapat melihat laporan pajak penghasilan secara individu, supervisor dapat melihat laporan pajak penghasilan karyawan yang berada dibawah pengawasannya. Manager dapat melihat semua laporan pajak penghasilan karyawan yang berada di bawah pengawasannya namun hanya pada 1 departemen terkait, HR Manager dapat melihat semua laporan. Finance Staff dapat melihat laporan pajak penghasilan sebagai acuan pengeluaran kas.

View Leave Report : karyawan dapat melihat laporan cuti/izin secara individu, supervisor dapat melihat laporan cuti/izin karyawan yang berada dibawah pengawasannya. Manager dapat melihat semua laporan cuti/izin karyawan yang berada di bawah pengawasannya namun hanya pada 1 departemen terkait.

View Overtime Report : karyawan dapat melihat laporan lembur secara individu, supervisor dapat melihat laporan lembur karyawan yang berada dibawah pengawasannya. Manager dapat melihat semua laporan lembur karyawan yang berada di bawah pengawasannya namun hanya pada 1 departemen terkait.

- Create Employee: HR Admin staff memasukan data karyawan dan HR manager juga dapat memasukan data karyawan jika HR Admin Staff sedang tidak bisa melakukan tugasnya.

- Update Employee : HR Admin staff mengubah data karyawan dan HR manager juga dapat mengubah data karyawan jika HR Admin Staff sedang tidak bisa melakukan tugasnya.

- Create Department: HR Admin staff memasukan data departemen dan HR manager juga dapat memasukan data departemen jika HR Admin Staff sedang tidak bisa melakukan tugasnya.

- Update Department: HR Admin staff mengubah data departemen dan HR manager juga dapat mengubah data departemen jika HR Admin Staff sedang tidak bisa melakukan tugasnya.

- Create Job Title: HR Admin staff memasukan data jabatan dan HR manager juga dapat memasukan data jabatan jika HR Admin Staff sedang tidak bisa melakukan tugasnya.

Update Job Title : HR Admin staff mengubah data jabatan dan HR manager juga dapat mengubah data jabatan jika HR Admin Staff sedang tidak bisa melakukan tugasnya.

- Create Leave: HR Admin staff memasukan data cuti dan HR manager juga dapat memasukan data cuti jika HR Admin Staff sedang tidak bisa melakukan tugasnya.

- Update Leave: HR Admin staff mengubah data cuti dan HR manager juga dapat mengubah data cuti jika HR Admin Staff sedang tidak bisa melakukan tugasnya.

- Create Shift : HR Admin staff memasukan data shift dan HR manager juga dapat memasukan data 
shift jika HR Admin Staff sedang tidak bisa melakukan tugasnya.

- Update Shift : HR Admin staff mengubah data shift dan HR manager juga dapat mengubah data shift jika HR Admin Staff sedang tidak bisa melakukan tugasnya.

- Create Calendar: HR Admin staff memasukan data calendar dan HR manager juga dapat memasukan data calendar jika HR Admin Staff sedang tidak bisa melakukan tugasnya.

- Update Calendar: HR Admin staff mengubah data calendar dan HR manager juga dapat mengubah data calendar jika HR Admin Staff sedang tidak bisa melakukan tugasnya.

- Create BPJS Health: HR Admin staff memasukan data BPJS kesehatan dan HR manager juga dapat memasukan data BPJS kesehatan jika HR Admin Staff sedang tidak bisa melakukan tugasnya.

- Update BPJS Health : HR Admin staff mengubah data BPJS kesehatan dan HR manager juga dapat mengubah data BPJS kesehatan jika HR Admin Staff sedang tidak bisa melakukan tugasnya.

- Create BPJS Employment: HR Admin staff memasukan data BPJS ketenagakerjaan dan HR manager juga dapat memasukan data BPJS ketenagakerjaan jika HR Admin Staff sedang tidak bisa melakukan tugasnya.

- Update BPJS Employment: HR Admin staff mengubah data BPJS ketenagakerjaan dan HR manager juga dapat mengubah data BPJS ketenagakerjaan jika HR Admin Staff sedang tidak bisa melakukan tugasnya.

- Create Income Tax Rate: HR Admin staff memasukan data penghasilan kena pajak dan HR manager juga dapat memasukan data penghasilan kena pajak jika HR Admin Staff sedang tidak bisa melakukan tugasnya.

- Update Income Tax Rate: HR Admin staff mengubah data penghasilan kena pajak dan HR manager juga dapat mengubah data penghasilan kena pajak HR Admin Staff sedang tidak bisa melakukan tugasnya.

- Create Non Taxable Income : HR Admin staff memasukan data penghasilan tidak kena pajak dan HR manager juga dapat memasukan data penghasilan tidak kena pajak jika HR Admin Staff sedang tidak bisa melakukan tugasnya.

- Update Non Taxable Income: HR Admin staff mengubah data penghasilan tidak kena pajak dan HR manager juga dapat mengubah data penghasilan tidak kena pajak $H R$ Admin Staff sedang tidak bisa melakukan tugasnya.

- Create COA: Finance staff memasukan data chart of account

- Update COA: Finance staff mengubah data chart of account

- LogOut: semua karyawan yang sudah melakukan login dapat melakukan logout

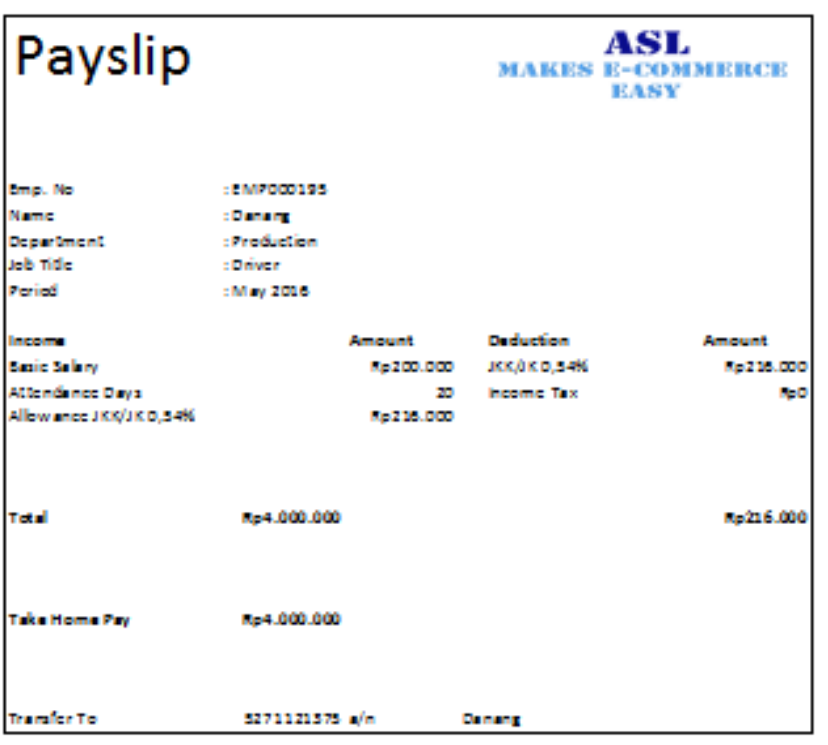

Gambar 1 Output Payslip Karyawan Harian

\section{KESIMPULAN}

Dengan merancang sistem absensi yang terintegrasi dengan database karyawan diharapkan dapat mengatasi permasalahan yang terjadi pada sistem absensi manual yang digunakan saat ini, sehingga waktu kerja diharapkan dapat terdokumentasi secara akurat dan meningkatkan pengendalian internal dengan pencatatan waktu secara otomatis. Perancangan sistem absensi yang terintegrasi dengan pengajuan cuti/izin juga diusulkan untuk mengatasi keterbatasan mesin finger print yang hanya dapat mencatat waktu kerja karyawan saja, sehingga diharapkan dapat mengurangi kesalahan perhitungan gaji akibat kesalahan pemotongan ketidakhadiran karyawan.

Terkait dengan masalah pengajuan cuti dan perhitungan kuota cuti secara manual, dapat dilakukan perancangan sistem pengajuan cuti yang terintegrasi dengan otorisasi cuti dan master karyawan, sehingga diharapkan dapat mengurangi kesalahan dalam pencatatan kuota cuti, perhitungan kuota cuti, otorisasi waktu cuti lebih cepat, dan pengarsipan pengajuan cuti lebih baik. Dengan merancang sistem pengajuan lembur dan perhitungan lembur yang terintegrasi dengan database karyawan dan absensi yang dapat melakukan perhitungan lembur secara otomatis untuk mengatasi masalah pengajuan, pencatatan, dan perhitungan lembur yang masih manual, sehingga diharapkan pencatatan waktu lembur dapat lebih akurat dan pengarsipan pengajuan lembur lebih baik. Perancangan sistem penugasan dinas yang terintegrasi dengan absensi karyawan, untuk mengurangi permasalahan kesalahan pemotongan gaji karena ketidakhadiran karyawan akibat karyawan ditugaskan dinas, sehingga diharapkan dapat mengurangi kesalahan perhitungan gaji karyawan akibat kesalahan pemotongan ketidakhadiran karyawan. 
Dengan merancang sistem perhitungan gaji yang terintegrasi dengan semua komponen penggajian yang dapat menghitung gaji secara otomastis untuk mengatasi masalah kesalahan perhitungan gaji, kesalahan perhitungan gaji dan keterlambatan pembayaran gaji karyawan sehingga dapat mengurangi beban kerja karyawan, mempercepat proses penggajian dan mengurangi kesalahan dalam perhitungan gaji karyawan.

Perancangan sistem penggajian yang mampu melakukan perhitungan pemotongan pajak penghasilan karyawan untuk mengatasi masalah penggunaan vendor untuk melakukan perhitungan pemotongan pajak, sehingga diharapkan PT ASL dapat mengurangi biaya penggunaan jasa vendor, menjaga data karyawan, dan memiliki sistem perhitungan pemotongan pajak penghasilan karyawan. Merancang sistem yang memiliki pengendalian internal seperti penggunaan password, otorisasi transaksi, transaction logging dan pembatasan akses sistem untuk mengatasi masalah pendataan master karyawan dan perhitungan gaji yang masih menggunakan Microsoft Excel, sehingga PT ASL dapat memiliki sistem yang pengendalian internal yang lebih memadai.

\section{DAFTAR PUSTAKA}

Chuang, H. (2015). International Journal of Business and Management. Competitive Advantages and Strategic Information Systems, 5(2015), 158-169. Retrieved from www.internationaljournal.org

Considine, B., Parkes, A., Olesen, K., Blount, Y., \& Speer, D.(2012). Accounting information System: Understanding Business Process. (4th Edition). Queensland: John Willey\&Sons Australia, Ltd.
Dinapoli, T. (2011). unternational journal of accounting information system. a content analysis of auditor's report on payroll internal control weakness : the comparative advantages of an automated approach to control weakness identification, 14(2011), 138-163.

Frank, J. (2915). International Journal of Academic Research in Accounting, Finance and Management Sciences. The Impact of the Motivation on the Employee's Performance in Beverage Industry of Pakistan, 4(2015), 293-298. Retrieved from http://hrmars.com/index.php/journals/papers/IJAR AFMS/v4-i1/630

Hall, J.A (2011). Accounting Information System . (7th Edition). Canada: South-Western, Cengage learning.

\section{SAK-ETAP Bab 23}

Satzinger , J.W., Jacson, R.B., \& Burd, S.D. (2005). Object-Oriented Analysis and Design with the Unified Process. (4th Edition). Oston: Course Technology, Cengage Learning.

Soemarso., R. (2009). Akuntansi Suatu Pengantar. (5th Edition). Jakarta: Salemba Empat

Weygandt, J.J., Kimmel, P.D., \&Kieso, D.E. (2011). Financial Accounting. (IFRS Edition). The United State of America: John Wiley and Sons,Inc.

Whitten, Jeffrey L., Bentley, Lonie D. (2007). System Analysis and Design Methods. (7th Edition). New York: $\mathrm{Mc}$

Graw-Hill. 